\title{
Investigation of the Response of onion (Allium Cepa L.) to continuous deficit irrigation as smart approaches to crop irrigation under Mediterranean conditions
}

\author{
Aziz Abouabdillah ${ }^{1 *}$, Omnia El Bergui ${ }^{1,2}$, Rachid Bouabid $^{1}$, Mohamed Bourioug $^{1}$, Youssef \\ Brouziyne $^{3}$, Nabil El Jaouhari ${ }^{4}$ and Ahmed Bouaziz ${ }^{2}$ \\ ${ }^{1}$ Ecole Nationale d'Agriculture de Meknès, Meknès, Morocco \\ ${ }^{2}$ Institut Agronomique et vétérinaire Hassan II, Rabat, Morocco \\ ${ }^{3}$ Mohammed VI Polytechnic University, International Water Research Institute, Benguerir, Morocco \\ ${ }^{4}$ Moulay Ismail University, Faculty of Science, Meknès, Morocco
}

\begin{abstract}
Water is a crucial resource for food production and its scarcity associated with frequent droughts has increased the need for a more efficient use of it along with new irrigation management technologies. This study addressed onion crop responses to continuous deficit irrigation with trigging thresholds of readily available water content. The experiment was conducted on an experimental plot in open field in Morocco. Three water regimes were applied T1 control (100\%), T2 (75\%) and T3 (50\%) of crop evapotranspiration ETc combined with two trigging thresholds (10\% and $5 \%$ ). This is a complete random block device with four repetitions. The measurements concerned the monitoring of vegetative, Eco physiological and yield parameters. The results obtained show that: (i) 100\% ETc irrigation at a threshold of $5 \%$ of RAW recorded the maximum bulb diameter and weight, thus achieving the best marketable bulb yields. However, in terms of yields, this treatment is not significantly different from the other irrigation regimes with the exception of the irrigated treatment at $50 \%$ daily ETc and at a threshold of $10 \%$ RAW. The latter recorded the lowest values in terms of production parameters. (ii) For the ecophysiological parameters, significant effects of irrigation dose were observed for proline content, stomatal conductance and leaf temperature, and the effect of the trigging threshold was clearly observed for the moisture content of the leaves. (iii) Water restrictions have minimized the rate of premature run and population density of Thrips tabaci in the onion. (iv) Finally, the best agronomic efficiencies in the use of irrigation water were recorded in treatments with a water restriction of $50 \%$.
\end{abstract}

Key word: Continuous deficit irrigation, onion, Crop coefficient, available water content

*Corresponding author: aziz.abouabdillah@,gmail.com 


\section{Introduction}

Decrease in water resources has become a worldwide problem and there may be insufficient water for food production by 2025 (Girona et al., 2010), especially in Mediterranean region which is a climate change "hot spot" (Abouabdillah et al., 2010). As a consequence, saving water in irrigation is the most critical issue to be considered (Ayas., 2019). Irrigation water is considered as acrucial element for crop production (Howell, 2001; Steduto et al., 2012; Abdelkhalik et al., 2019). In Morocco, about $75 \%$ of water is allocated to agriculture (Abdelkhalik et al., 2019). Therefore, agriculture is a key sector in the Moroccan economy, as it represents approximately 15\% of the Gross Domestic Product (Brouzyine et al., 2018). It should be pointed out that $43 \%$ of Moroccan population makes a living from agricultural activity (Bzioui, 2004). Actually, major challenges exist in maximizing water use efficiency (WUE) and increasing crop productivity per unit of water applied. Within this context, deficit irrigation (DI) is used as a practice that provides water below optimal crop water requirements leading to increased WUE (Pereira et al., 2002; Costa et al., 2007; Fereres and Soriano, 2007; Capra et al., 2008; Evans and Sadler, 2008; Sharma et al., 2014 : Chai et al., 2016). However, DI can save a significant amount of irrigation water with the risk of reducing the yield of some crops. Generally, a distinction is made between two types of deficit irrigation that can be applied: Sustainable Deficit Irrigation (SDI) which means the application of continuous water restriction throughout the entire crop cycle (Goldhamer et al., 2006), or a water stress during particular crop developmental periods (RDI: Regulated Deficit Irrigation) (English et al., 1990; Chalmers et al., 1981; Hueso and Cuevas, 2004).

Among vegetable crops, onion is one of the main foods widely used around the world. According to the most recent data of the United Nations Food and Agriculture Organization (FAO), worldwide onion production was approximately 96.7 million tons from 5.03 million hectares (FAO, 2018). Average world yields increased from 18.4 t/ha in 2004 to $19.2 \mathrm{t} / \mathrm{ha}$ in 2018. The leading onion producing countries are China, India and the Unites States of America accounting for $20 \%$ of the world production (FAO, 2018). Based on FAO data, Morocco produces 954801 tons of onions annually, which is approximately $1 \%$ of the world's onion production. This study was carried out in the Fes-Meknes region of Morocco. This region is the country's leading onion producer, accounting $54 \%$ of the total production.

Water requirements for onion varies depending on location and irrigation system (LópezUrrea, 2009). The maximum root penetration of onion is $76 \mathrm{~cm}$, but most of itis in the first $18 \mathrm{~cm}$ of soil limiting the amount of soil water available for roots (Hanci and Cebeci, 2014). As a result, rainfall is insufficient to sustain its production, making irrigation crucial.

Some previous experiments on onion field grown in different climates were studied. Deficit irrigation (50\% ETc) saved $50 \%$ of irrigation water with a $25 \%$ reduction in bulb yield while at $75 \%$ of ETc, the reduction in bulb yield is not significant in comparison with the control (Igbadun et al., 2012). Deficit irrigation increased the water use efficiency of the onion (Santa Olalla et al., 2004; Singh et al., 2017; Igbadun et al., 2012). In addition to water savings, deficit irrigation may also have positive effects on fruit quality (Sharma et al., 2014). Therefore, the objectives of this study were to determine optimal irrigation parameters for yield optimization and increased water use efficiency, as well as to study the combined effect of deficit irrigation and irrigation frequencies on the onion crop.

\section{Materials and methods}




\subsection{Experimental site and climatic conditions}

The field experiment was conducted during the growing season of 2018 from April to august at the National School of Agriculture of Meknes, situated in Fès-Meknès region, Morocco(Fig. 1). Its geographical coordinates are: latitude $33^{\circ} 50^{\prime} 36^{\prime \prime} \mathrm{N}$, longitude $5^{\circ} 28^{\prime} 39^{\prime}$ ' $\mathrm{W}$ and its altitude is $546 \mathrm{~m}$ above sea level. The soil texture at the site is loamy-clayey. The volumetric water content for the first $0.3 \mathrm{~m}$ was $38 \%$ at field capacity and $21.3 \%$ at wilting point. Soil characteristics are detailed in Table 1.

The climate of the study area is Mediterranean with an average annual rainfall of approximately $450 \mathrm{~mm}$. Maximum and minimum temperature values at the experimental site during the experiment were $40^{\circ} \mathrm{C}$ and $4^{\circ} \mathrm{C}$, respectively (Fig. 2a). The highest and lowest relative humidity values were found as $100 \%$ and $16 \%$, respectively. As shown in Fig. 2(b), daily reference evapotranspiration, values vary between 0.5 and $7 \mathrm{~mm}$. Rainfall during the irrigation season was $55 \mathrm{~mm}$, which was taken inconsideration in the irrigation water allocation for each treatment.

Table 1.Soilphysico-chemical characterization at the experimental site.

\begin{tabular}{|c|c|}
\hline Parameters (unit) & Soil property \\
\hline Clay (\%) & 37.3 \\
\hline Silt (\%) & 56.5 \\
\hline Sand (\%) & 16.2 \\
\hline Electrical conductivity (dS m-1) & 0.102 \\
\hline pH & 8.41 \\
\hline Total limestone (mg kg-1) & 24.4 \\
\hline Organic matter (\%) & 2.78 \\
\hline Mineral nitrogen (mg kg-1) & 25.9 \\
\hline Olsen P2O5 (mg kg-1) & 9.0 \\
\hline Extractable K2O (mg kg-1) & 317.0 \\
\hline
\end{tabular}

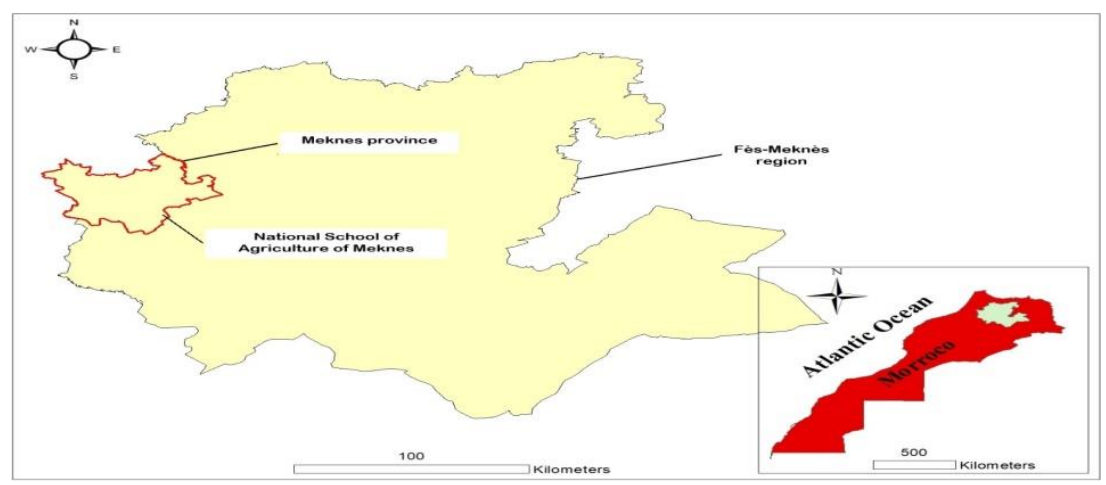

Fig. 1.Geographic location of the experimental site (prepared using ArcGIS software 10.3). 

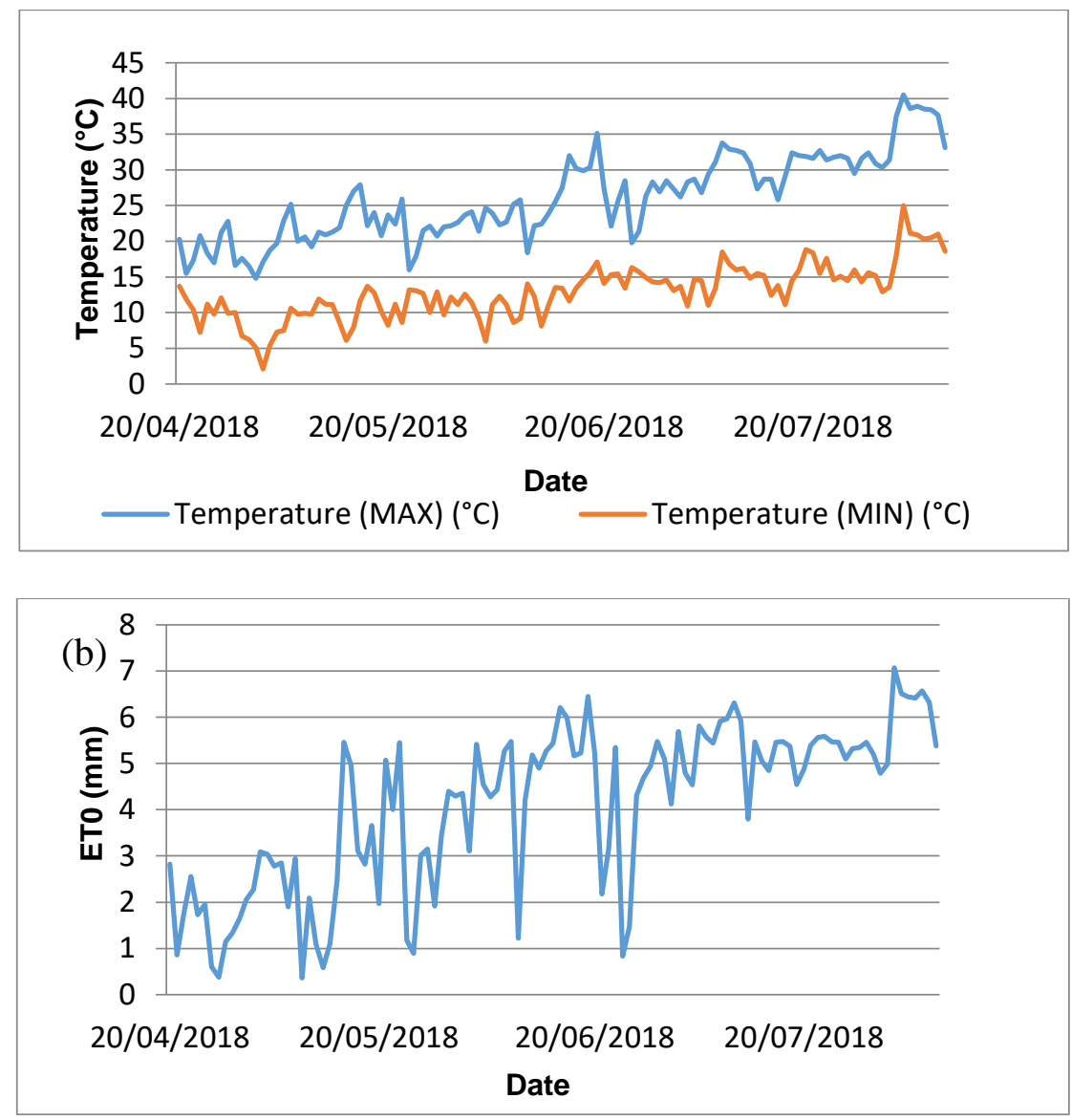

Fig. 2.Daily Average (a) temperature $\left({ }^{\circ} \mathrm{C}\right)(\mathrm{b})$ reference evapotranspiration (ET0) during the growing season

\subsection{Crop Management}

The onion plant (Allium cepa L.) was transplanted on April 29, 2018 at a spacing of $0.1 \mathrm{~m}$ by $0.8 \mathrm{~m}$ at a depth of $1 \mathrm{~cm}$. After transplanting, all treatments were fully irrigated to restore the soil moisture content to the field's capacity. The type and rate of application was based on the results of the soil analysis. Fertilizer units applied during the crop cycle were $73 \mathrm{~kg} / \mathrm{ha}$ $\mathrm{N}, 44 \mathrm{~kg} / \mathrm{ha} \mathrm{P} 2 \mathrm{O} 5$ and $60 \mathrm{~kg} / \mathrm{ha} \mathrm{K} 2 \mathrm{O}$. The crop was harvested 99 days after transplanting, when the bulb onions were mature. Mature bulb onions were hand pulled from the ground and sun-dried for one month and then stored in silos before measuring yield and quality parameters.

\subsection{Irrigation treatments and experimental design}

The plot is provided with a drip irrigation system. Each planting line has a single polyethylene drip line, with self-regulating drippers, uniformly spaced $40 \mathrm{~cm}$ apart on the drip line and delivering 1.6 1/hour. Crop evapotranspiration (ETc) was calculated using the following formula(Allen at al., 1998) :ETc $(\mathrm{mm})=($ ET0 x Kc) - effective rainfall. ET0 is the reference daily evapotranspiration calculated by the modified Penman-Montheith formula based on climatic parameters collected continuously from a weather station located approximately 30 
$\mathrm{m}$ from the experimental site. The Kc used in this study is that published by López-Urrea (2009)(Table 2). Effective rainfall is the fraction of precipitation that directly meets the crop water requirements, it corresponds to $80 \%$ of total rainfall, taking in consideration the amount of rain lost through surface runoff, deep percolation or evaporation (El Jaouhari et al., 2018). In this experiment there were six treatments combining three doses of irrigation $(100 \%, 75 \%$ and $50 \%$ of daily ETc) and two thresholds of the Readily available water RAW (10\% and 5\%). On the one hand, a threshold of $10 \%$ with $100 \%$ (T1), $75 \%$ (T2) and $50 \%$ (T3) of ETc, on the other hand a threshold of $5 \%$ with $100 \%$ (T4), $75 \%$ (T5) and $50 \%$ (T6) of ETc throughout the cycle.

In order to determine the water amount to be applied for each irrigation, it was necessary to calculate the Readily Available Water (RAW) equivalent to the Net Maximal Amount of irrigation, which corresponds to the amount of water that a soil can hold in the effective root depth, and which is calculated by using the formula below:

RAW $=f \times(F c-P W P) \times$ Rd $x$ PHS

With

f: Irrigation triggering threshold (5\%) and $10 \%$ in this study

Fcc: Humidity at field capacity

Hpfp: Humidity at permanent wilting point

Rd: effective root depth

PHS: Percentage of humidified soil using the installed drip irrigation system

All the key parameters of the RAW were calculated at the beginning of the experiment. The factor $\mathrm{f}$ is an important indicator for judging the work quality in irrigation management.

The values of $\mathrm{f}$ chosen for this test were $5 \%$ and $10 \%$.

The basic meaning of $\mathrm{f}=5 \%$ or $10 \%$ is that irrigation is triggered when $5 \%$ or $10 \%$ of the available soil water storage is consumed.

A randomized complete block design was used with four block replicates. Each replicated block contained all six treatments. Each elementary plot consisted of six planting line of 20 m long each.

Table 2. Proposed Kc model for onion growing by López-Urrea (2009).

\begin{tabular}{|c|c|c|}
\hline Stage & Kc & Duration \\
\cline { 1 - 2 } 1 leaf & 0.70 & \multirow{2}{*}{52} \\
2 leaf & 0.80 & \\
\hline 3 to 4 leaf & 0.90 & 62 \\
\hline Bulb growth & 1.05 & \multirow{2}{*}{30} \\
\cline { 1 - 2 } Bulb thickening & 1.20 & \\
\hline Ripening & 0.7 & 24 \\
\hline
\end{tabular}

\subsection{Data analysis}

Statistical analysis methods were used to analyze the data obtained from the experiment for the effect of water stress and irrigation frequency on yield and quality components of onions. Analysis tools used comprised Analysis of Variance (ANOVA) and Student-Newman-Keuls 
(SNK) multiple comparison test using SPSS software (version 20). Treatments effects were considered significant at $\mathrm{P}<0.05$.

\subsection{Plant measurements}

\subsubsection{Growth parameters}

For growth monitoring, observations and measurements included leaf number and plant height. They were carried out every 15 days during the trial period on 48 selected randomly (8 plants per treatment). Plant height $(\mathrm{cm})$ was measured using a double decameter.

The Relative Growth Rate (RGR in cm.cm-1.j-1) is an indicator of plant growth and was calculated in relation to plant height measurements according to the following equation (James and Richards, 2006) :

$$
\operatorname{RGR}(\mathrm{cm} . \mathrm{cm}-1 \text { day }-1)=\frac{\operatorname{Ln}(\text { Height }) \mathrm{t} 2-\operatorname{Ln}(\text { Height }) \mathrm{t} 1}{\mathrm{t} 2-\mathrm{t} 1}
$$

Where $:($ Height $) \mathrm{t} 1=$ plant height measured at time $\mathrm{t} 1$; (Height $) \mathrm{t} 2=$ plant height measured at time $\mathrm{t} 2$; $\mathrm{t} 2-\mathrm{t} 1=$ the number of days between (Height) $\mathrm{t} 1$ and (Height) $\mathrm{t} 2$.

\subsubsection{Eco-physiological parameters}

In this study, the relative chlorophyll content was non-destructively measured with the use of chlorophyll content meter model CCM-200 (Opti-Sciences, Inc., Hudson, NH). Three measurements were taken every 20 days on a random sample of 24 plants per treatment. The stomatal conductance was measured on mature leaves using a porometer (Leaf Porometer Decagon Devices, INC). Three leaf temperature measurements were taken using an infrared thermometer on two plants per experimental unit.

The leaf relative water content (LRWC; \%) was determined in fresh leaf discs. The discs were weighed (FW), and immediately floated on water to saturate them with for $6 \mathrm{~h}$ in darkness. The adhering water of the discs was blotted, and turgor weight (TW) was recorded. After dehydration at $70^{\circ} \mathrm{C}$ for $48 \mathrm{~h}$, the dry weight (DW) of the disc was noted. LRWC was calculated using the equation developed by Turner (1981) :

$$
\operatorname{LRWC}(\%)=\frac{F W-D W}{T W-D W} \times 100
$$

Proline was extracted from a sample of $100 \mathrm{mg}$ fresh leaves and roots crushed for each treatment in $10 \mathrm{ml}$ of $3 \%$ aqueous sulpho-salycylic acid and estimated using the ninhydrin reagent according to the method described by Bates et al. (1973). The absorbance of fraction was read at a wavelength of $520 \mathrm{~nm}$. Concentration of proline (expressed as $\mu \mathrm{mol} \mathrm{g-1} \mathrm{of} \mathrm{fresh}$ weight) was determined by referring to a calibration curve prepared from a standard range of proline based on the following concentrations: $5,10,15,20$ and $25 \mu \mathrm{g} / \mathrm{ml}$ proline per tube.

\subsubsection{Fruit yield, quality and water use efficiency}

The average bulb weight per treatment was determined for two plants from each experimental unit were randomly picked. The marketable bulb yield (MBY)per treatment was calculated using the bulb weight and the number of plants per line. The equatorial diameter ( $\mathrm{mm})$ of 
onion bulbs were measured using a digital caliper as one of the parameters of crop quality (Rop, 2007).

Water use efficiency (WUE) is the ratio between the fruit yield (kg.ha-1) obtained and the amount of water applied (m3) (Bouaziz et al., 2002). The WUE was calculated as follows:

$$
\text { WUE }(\mathrm{kg} / \mathrm{m} 3)=\frac{\text { Yield }(\mathrm{kg} / \mathrm{ha})}{\text { total of water received }(\mathrm{mm})}
$$

\section{Results and discussion}

\subsection{Growth parameters}

The evolution of the growth parameters (Leaf number, plant height, root mass and volume) is presented in Fig. 3. During the experiment, the six applied irrigation regimes did not show any significant effect. Fig. 3 (a) indicated that the highest average number of leaves per plant (8.29 leaves) was recorded within T2, while T6 recorded the lowest leaves number (7.54 leaves). These results are in accordance with Enchalew et al. (2016), who reported that the highest onion leaves number was found in the treatment receiving 90\% ETc and up to $20 \%$ water restriction was tolerable to obtain at least seven leaves per plant. Karim (1981) worked on the effect of irrigation frequencies on the onion crop and reported that as soil water supply increased, plant growth parameters increased. Fig.3 (b) shows that plant growth was influenced with the amount of water applied between the treatment. The evolution of onion plant height followed the same pattern, with the exception of the T6 treatment where the decrease in height started as early as the 68th day after transplanting. The average height of plants varies most of the time between 39 and $48 \mathrm{~cm}$. Our results do not match with those of Bagali (2010) who noted that the plant height show a significant effect of irrigation frequency as the highest heights were observed at $100 \%$ of ETc. In the same study by Enchalew et al. (2016), the highest and lowest plant heights were obtained within the treatments receiving $90 \%$ and $50 \%$ ETc, respectively. However, another study, published by Kanton et al. (2003), who examined the effect of irrigation frequency on onion crop, indicates that as irrigation intervals increased, plant height decreased significantly. The effect of SDI and irrigation frequencies on relative growth rate (RGR) are shown in Fig. 3(c). The RGR peaks are reached between days 68 and 82 after transplanting for the T1 treatment, and between days 56 and 68 after transplanting for the rest of treatments. However, significant difference was found between T1 and the others treatments. The highest RGR was recorded by T1 during the 1426 day interval after transplanting. Our results showed that the highest relative growth rate is obtained in the non stressed treatment, which is consistent with the results of Galmes et al. (2005). It was found by Hegde (1986) that irrigation had no significant effect on onion RGR except between 21 and 35 days after transplanting. 

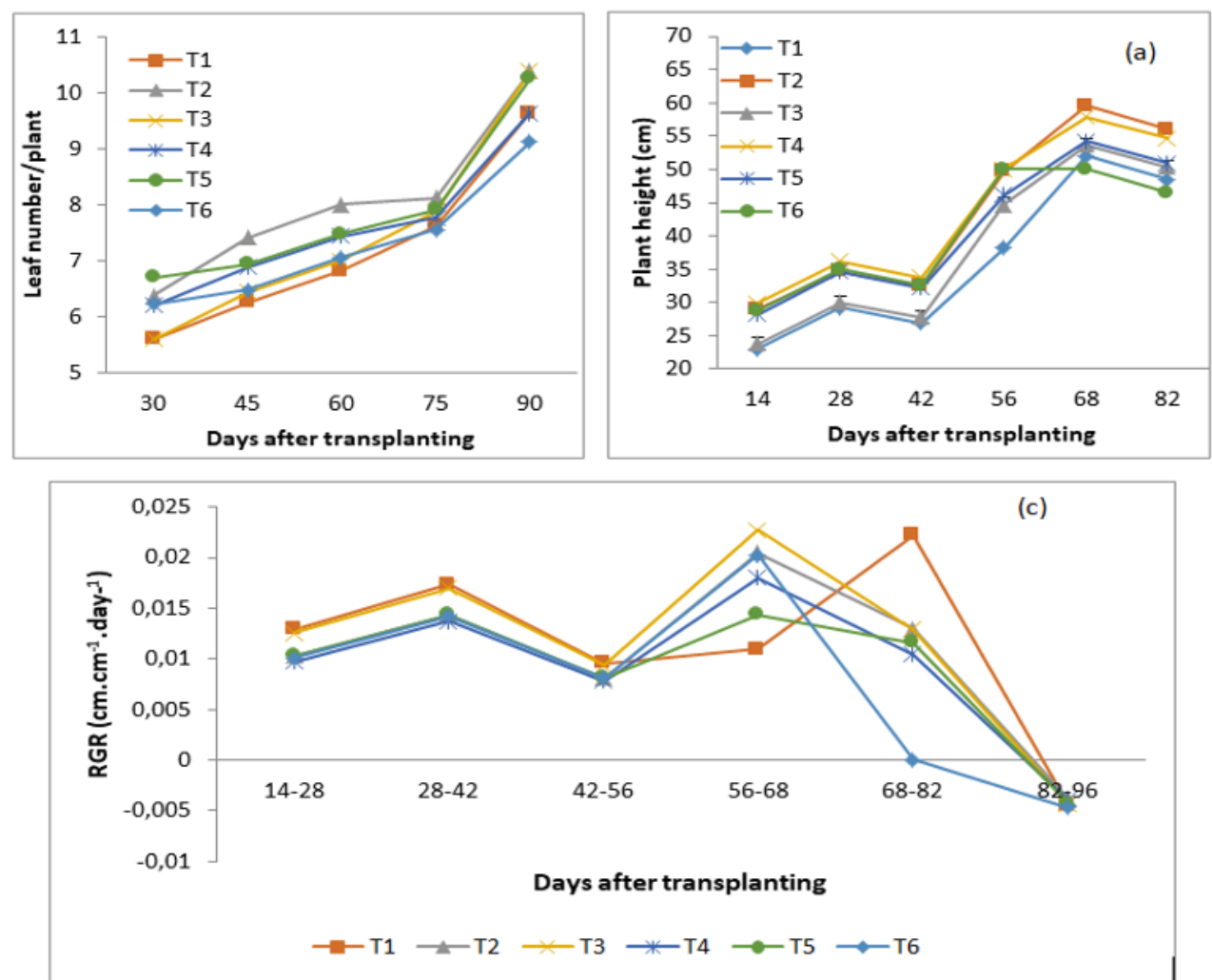

Fig. 3.Plant growth (a) number of leaves per plant, (b) plant height, (c) evolution of the relative growth rate after transplanting

\subsection{Eco-physiological parameters}

The relative chlorophyll content was unaffected significantly by the irrigation doses and frequencies. Indeed, T4 treatment had the highest value and the lowest was recorded by T3, T5 and T6 treatments (Fig. 3A). Pirzad et al. (2011) concluded that a water stress (excessive or deficit water) decreases significantly leaf chlorophyll concentrations (chlorophyll-a, chlorophyll-b and total chlorophyll). It was found that water deficit can destroy or prevent the production of chlorophyll (Montagu and Woo, 1999). For the stomatal conductance, significant effect of SDI treatments (T3 and T6) was observed (Fig. 3B). The results of this study are not in accordance with those obtained by Cornic and Briantais (1991), who noted that the stomatal conductance increases for treatments receiving more water. In this experiment, it may be due to the fact that T1, T2, T4 and T5 treatments plants were not stressed during the measurement. A significant difference was discerned between the treatments under SDI for leaf temperature (Fig. 3C). The lowest values were 27.75 and 27.25 ${ }^{\circ} \mathrm{C}$ recorded in the T1 and T4 treatments, respectively. According to Hsiao (1973), the increase in leaf temperature depends strongly on environmental factors. 

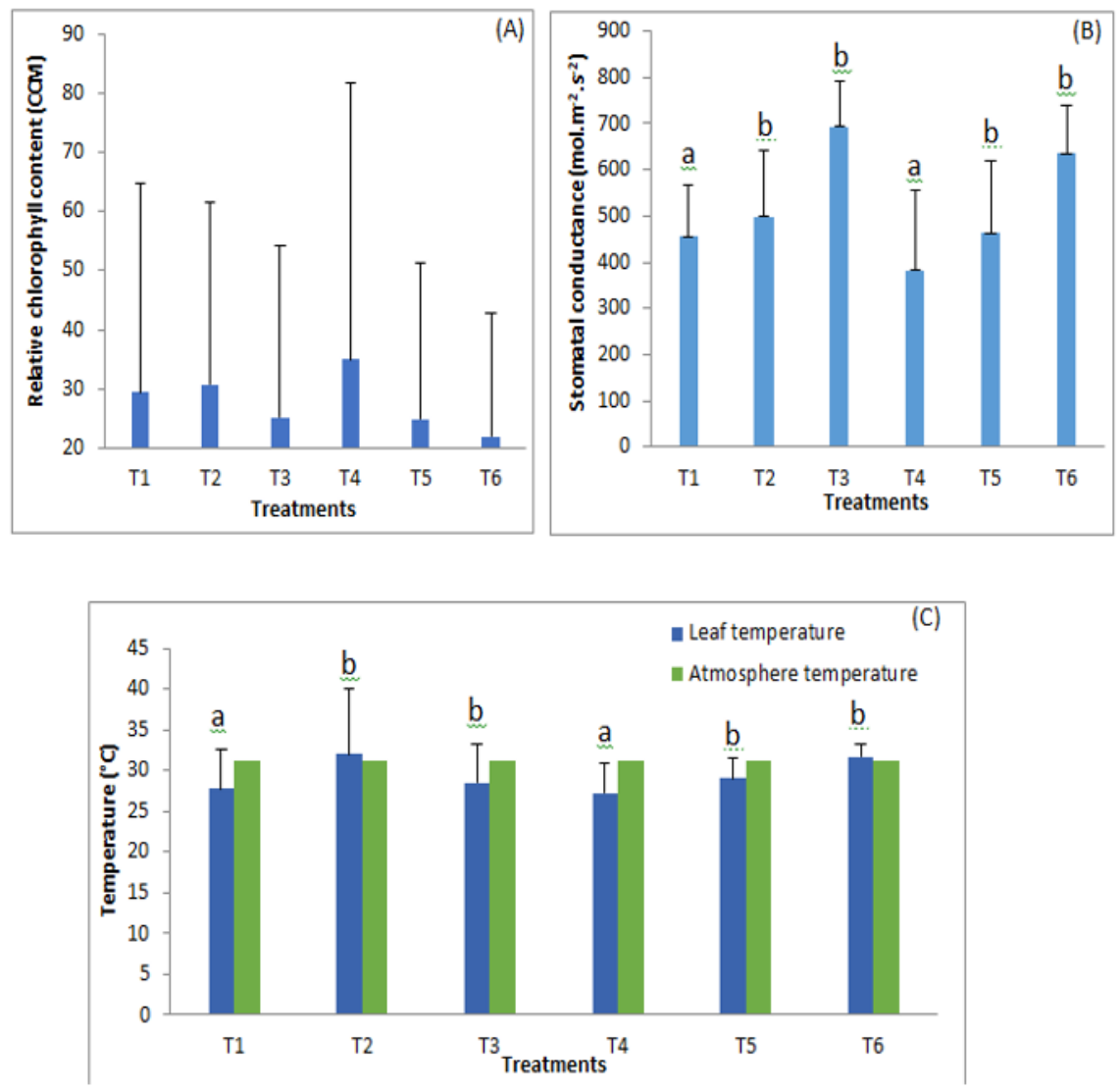

Fig.4.Eco-physiological parameters (A) relative chlorophyll content, (B) stomatal conductance, (B) leaf temperature under different irrigation treatments. Different letters indicate significant differences according to the SNK test at $\mathrm{p}<0.05$. The error bars show the standard deviation of measurements between replications.

Deficit irrigation at $50 \%$ of ETc had significant effect on proline content (Fig. 5). Proline value increased significantly under drought stress regardless of frequency. The highest concentration of proline was found in plants that were under maximum stress $(50 \%$ of the ETc throughout the cycle) within the T3 and T6 treatments, in comparison with other treatments. Plants generally accumulate free proline in response to many environmental stresses (Hare and Cress, 1997). The results obtained in this study are considered similar to those obtained by Pirzad et al. (2011) and those found by Delauney and Verma (1993), in which maintaining high-water levels prevents the accumulation of osmotic elements, such as proline and total soluble sugars. 


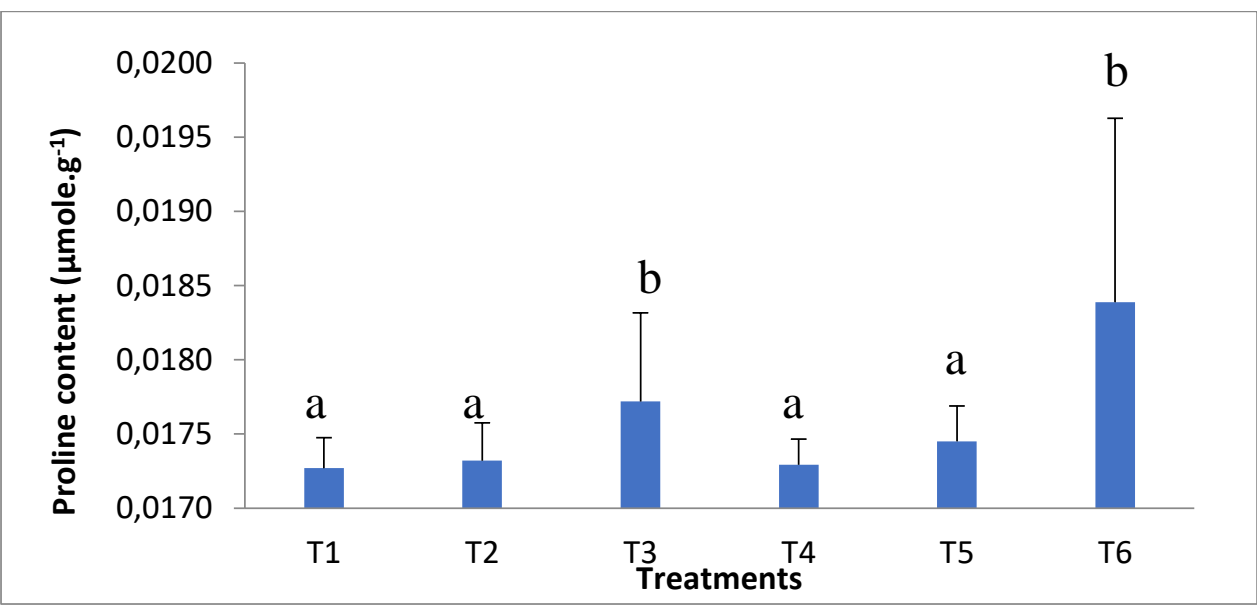

Fig. 5.Effect of different irrigation treatments on proline content. Different letters indicate significant differences according to the SNK test at $\mathrm{p}<0.05$. The error bars show the standard deviation of measurements between replications.

The results of variance analysis highlighted the presence of significant effect of the irrigation frequency factor on the leaf relative water content during the experiment, the irrigation regime did not have an effect on this parameter. The LRWC values for T1, T2, T3, T4, T5 and T6 were 92.74, 93.98, 91.65, 95.47, 95.31 and 95.66\%, respectively. Treatments with 5 $\%$ threshold (T4, T5 and T6) had the highest LRWC values (Fig. 6). It appears that LRWC increases with decreasing the threshold of the RAW. Surendar et al. (2013) reported that a reduction of net photosynthesis when the LRWC was reduced.

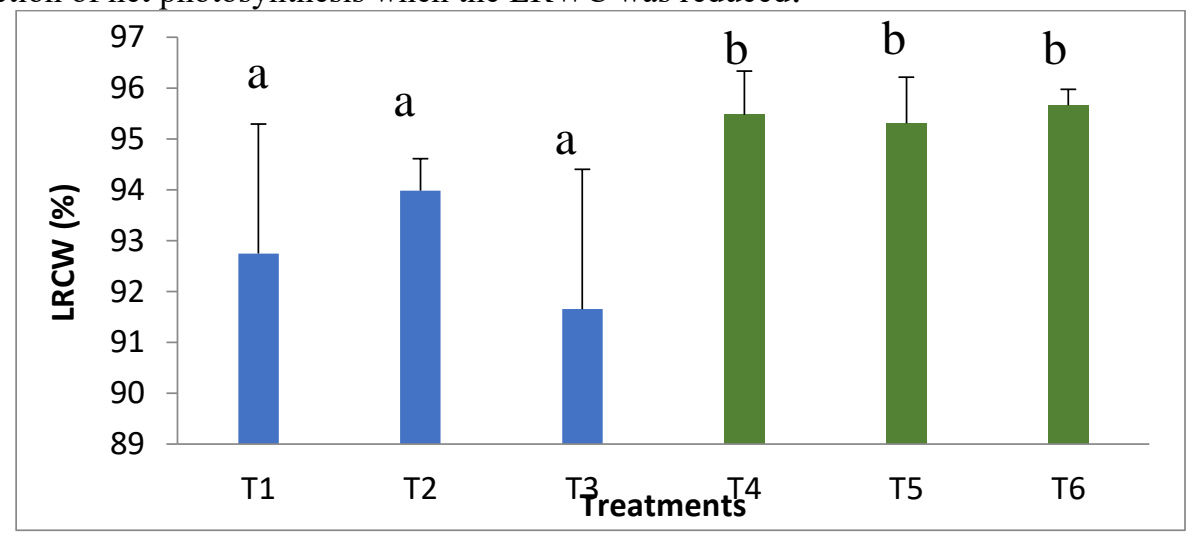

Fig. 6. Effect of different irrigation treatments on leaf relative water content (LRWC) of onion plants. Different letters indicate significant differences according to the SNK test at $\mathrm{p}<0.05$. The error bars show the standard deviation of measurements between replications.

\subsection{Fruit yield, quality and water use efficiency}

In the present study, no significant differences were observed between the six treatments concerning the marketable bulb yield (MBY) (Table 3). The T4 treatment reached the highest MBY (36.9 t/ha), followed by the T2 treatment (34.9 t/ha). It should be noted that in our study, as a result of experimental constraints, we planted at a density of 134,663 plants/ha, whereas the known planting density in the region varies between 200,000 and 250,000 plants/ha. This is in agreement with the findings of Santa Ollala et al. (2004), who did not 
obtain in their experiment a significant difference in dry matter yied between treatments that were water restricted at different levels and those that received $100 \%$ of their water requirements. Other studies (Hegde, 1986; Al-Jamal et al., 2000) showed that onions can reach maturity with different levels of water restriction. According to Pelter et al. (2004), water stress can reduce the yield of yellow onion and that the greatest reduction could be observed when irrigation is withheld at the 5-leaf, 7-leaf stage. The highest onion yields have been recorded among low RAW thresholds (Mermoud et al., 2005). Irrigation at $100 \%$ of the field capacity every 2 days recorded the maximum yield (Mbagwu et al. (1985). Statistical analysis showed a highly significant effect of the interaction between dose and frequency on bulb weight (Table 3). Bulb weight varied significantly between the T4 and the rest of treatments. Irrigation at $100 \%$ ETc with $5 \%$ RAW threshold produced the maximum bulb weight. These results are in line with Al-Moshileh (2007), which indicates that a high application of soil moisture leads to significant photosynthesis. Onion bulb diameter was found not being significantly influenced by the irrigation treatments applied. The largest diameter $(70 \mathrm{~mm})$ was from T4 which received maximum amount of water with $5 \%$ RAW threshold while T5 treatment gave the smallest diameter (Table 3). Santa Ollala et al. (2004) found the similar results, considering that the increase in bulb was attributed to the enhancement in the water quantity applied. The highest onion bulb diameter was recorded by the irrigation at $100 \%$ ETc (Enchalew et al., 2016).

The reduction of $50 \%$ ETc in irrigation water amount had a significant increase in the WUE, reaching $0.83 \mathrm{~kg} / \mathrm{m} 3$ and $0.93 \mathrm{~kg} / \mathrm{m} 3$ for T3 and T6, respectively (Table 3). The lowest WUE was $0.52 \mathrm{~kg} / \mathrm{m} 3$ obtained with the irrigation level equivalent to $100 \%$ ETc and $10 \%$ RAW threshold. The maximum WUE for onion was obtained in treatment with $50 \%$ restriction in irrigation water quantity compared to control (Shock et al., 2000; Kebede, 2003). This result is supported by the results of Singh et al. (2017). With deficit irrigation, the reduction in yield is compensated by increased production from the additional irrigated area with the water saved (Ali et al., 2007).

Table 3. Effect of the irrigation dose and frequency on marketable bulb yield (MBY), bulb weight (BW), bulb diameter (BD) and water use efficiency (WUE). Mean values followed by different letters

in each column indicate significant differences at $\mathrm{P} \leq 0.05$ according to the SNK test.

\begin{tabular}{|c|c|c|c|c|}
\hline Treatment & $\begin{array}{c}\text { MBY } \\
(\mathbf{t} / \mathbf{h a})\end{array}$ & $\mathbf{B W ( g )}$ & $\mathbf{B D}(\mathbf{m m})$ & $\begin{array}{c}\text { IWUE } \\
\left(\mathbf{k g} / \mathbf{m}^{\mathbf{3}}\right)\end{array}$ \\
\hline T1 & $34.2 \mathrm{a}$ & $292.1 \mathrm{a}$ & $65.6 \mathrm{a}$ & $0.52 \mathrm{a}$ \\
\hline T2 & $34.9 \mathrm{a}$ & $286.1 \mathrm{a}$ & $67.5 \mathrm{a}$ & $0.71 \mathrm{a}$ \\
\hline T3 & $27.0 \mathrm{a}$ & $318.9 \mathrm{a}$ & $60.6 \mathrm{a}$ & $0.83 \mathrm{~b}$ \\
\hline T4 & $36.9 \mathrm{a}$ & $381.1 \mathrm{~b}$ & $70.0 \mathrm{a}$ & $0.57 \mathrm{a}$ \\
\hline T5 & $28.2 \mathrm{a}$ & $302.3 \mathrm{a}$ & $60.1 \mathrm{a}$ & $0.58 \mathrm{a}$ \\
\hline T6 & $30.1 \mathrm{a}$ & $300.0 \mathrm{a}$ & $64.6 \mathrm{a}$ & $0.94 \mathrm{~b}$ \\
\hline
\end{tabular}

\section{Conclusion}

In this study, the effect of sustainable deficiency irrigation and irrigation frequencies are being tested on the growth, yield and quality of the onion crop. Our results showed no significant effect on growth parameters and relative chlorophyll content. The sustainable 
water restriction to $75 \%$ of the crop water requirement increased proline content and water use efficiency compared to the $100 \%$ ETc control irrigated treatment throughout the cycle.. However, this treatment recorded the highest marketable bulb yield with a RAW threshold of $10 \%$. Severe deficit irrigation at $50 \%$ of the water requirement could significantly influence stomatal conductance and leaf temperature, and also recorded the lowest values in terms of yield and quality parameters. Concerning the eco-physiological parameters; total chlorophyll, no significant difference was generated except for the leaf relative water content, which was significantly affected by the irrigation frequency. According to this study, it is advisable to apply $100 \%$ of water requirements with a trigging threshold of the readily available water content of $5 \%$, if water is not a limiting factor. But, if water is rare, it could be better to apply $75 \%$ of water requirements, saving $25 \%$ of irrigation water without having a significant effect on production and quality.

\section{Acknowledgements}

This work has been carried out under the auspices of the MCRDV research project MCRDV "COMPETITIVE MECHANISM OF DEVELOPMENT RESEARCH ANDVULGARISATION" and we gratefully acknowledge the financial support provided by the

Ministry of Agriculture, Fisheries, rural development, water and forest. We are also grateful to the National School of Agriculture of Meknes (ENAM) for their support andcooperation during the project which made this work possible.The authors also wish to thank students Lamrahli Douae, and Dahane Mahdi for their valuable contribution during their final engineering projects.

\section{References}

1. A. Abdelkhalik, N. Pascual-Seva, I. Nájera, A. Giner, C. Baixauli, B. Pascual, 2019. Yield response of seedless watermelon to different drip irrigation strategies under Mediterranean conditions. Agric. Water Manage. 212, 99-110.

2. A. Abouabdillah, O. Oueslati, A.M. De Girolamo, A. Lo Porto, 2010. Modeling the impact of climate change in a Mediterranean catchment (Merguellil-Tunisia). Fresenius Environ. Bull. 19, 2334-2347.

3. A.Al- Moshileh, 2007. Effects of planting date and irrigation water level on onion (Allium cepa L.) production under central Saudi Arabian conditions. J Basic Appl Sci. 8, 14-28.

4. A. Bouaziz, K. Belabbes, 2002. Efficience productive de l'eau en irrigué au Maroc. Hommes, Terre \& Eaux, 32, 4p.

5. A. Capra, S. Consoli, B. Scicolone, 2008. Water management strategies under deficit irrigation. J. Agric. Eng. 39, 27.

6. A. J. Delauney, D. P. S. Verma, 1993. Proline biosynthesis and osmoregulation in plants. PLANT J, 4, 215-223.

7. A. Mermoud, T. D. Tamini, H. Yacouba, 2005. Impacts of different irrigation schedules on the water balance components of an onion crop in a semi-arid zone. Agric. Water Manage. 77, 282-295.

8. A. N. Bagali, 2010. Studies on Integrated Nutrient Management and Scheduling of Drip Irrigation in Onion (Allium cepa L.) cv. Telagi Red (Doctoral dissertation, UAS Dharwad).

9. A. Pirzad, M. R. Shakiba, S. Zehtab-Salmasi, S. A. Mohammadi, R. Darvishzadeh, A., Samadi, 2011. Effect of water stress on leaf relative water content, chlorophyll, proline and soluble carbohydrates in Matricaria chamomilla L. J. Med. Plant Res. 5, 2483-2488. 
10. A. Singh, S. K. Srivastava, K. J. Kumar, D. M. Denis, A.Thomas, 2017.Yield, irrigation production efficiency and economic return of onion under variable irrigation methods. The allahabad farmer, 73(1).

11. Al-Jamal, M. S., Sammis, T. W., Ball, S., Smeal, D., 2000. Computing the crop water production function for onion. . Agric. Water Manage. 46, 29-41.

12. B. Enchalew, S. L. Gebre, M. Rabo, B. Hindaye, M. Kedir, 2016. Effect of Deficit Irrigation on Water Productivity of Onion (Allium cepal.) under Drip Irrigation. Irrigat Drainage Sys Eng. 5 :172. doi : 10.4172/2168-9768.1000172

13. D. K. Rop, E. C. Kipkorir, J. K. Taragon, 2016. Effects of Deficit Irrigation on Yield and Quality of Onion Crop. J. Agric. Sci. 8, 112.

14. D. M. Hegde, 1986. Growth analysis of onion (Allium cepa L.) in relation to irrigation and nitrogen fertilization. J AGRON CROP SCI. 157, 227-234.

15. D.J. Chalmers, P.D. Mitchell, L. van Heek, 1981. Control of peach tree growth and productivity by regulated water supply, tree density, and summer pruning. J AM SOC HORTIC SCI. 106, 307-312.

16. E. Fereres, M.A. Soriano, 2007. Deficit irrigation for reducing agricultural water use. J. Exp. Bot. 58, 147-159.

17. F. Hanci, E. Cebeci, 2014.Investigation of Proline, Chlorophyll and Carotenoids Changes Under Drought Stress in Some Onion (Allium Cepa L.) Cultivars. TURKJANS. 2, 14991504.

18. F. M. Santa Olalla, A. Domınguez-Padilla, R. Lopez, 2004. Production and quality of the onion crop (Allium cepa L.) cultivated under controlled deficit irrigation conditions in a semi-arid climate. Agric. Water Manage. 68, 77-89.

19. Food and Agriculture Organization of the United Nations (FAO), 2018. FAOSTAT Website. Accesed on 12 May 2020. http://www.fao.org/faostat/en/\#data.

20. G. Cornic, J. M. Briantais, 1991. Partitioning of photosynthetic electron flow between $\mathrm{CO} 2$ and $\mathrm{O} 2$ reduction in a $\mathrm{C} 3$ leaf (Phaseolus vulgaris L.) at different $\mathrm{CO} 2$ concentrations and during drought stress. Planta. 183, 178-184.

21. G. Q. Pelter, R. Mittelstadt, B. G. Leib, C. A. Redulla, 2004. Effects of water stress at specific growth stages on onion bulb yield and quality. . Agric. Water Manage. 68, 107115.

22. Goldhamer, DA., Viveros, M., Salinas, M., 2006. Regulated deficit irrigation in almonds : effects of variations in applied water and stress timing on yield and yield components. Irrig. Sci. 24, 101-114.

23. H.E. Igbadun, A.A. Ramalan, E. Oiganji, 2012.Effects of regulated deficit irrigation and mulch on yield, water use and crop water productivity of onion in Samaru, Nigeria. Agric. Water Manage. 109, 162-169

24. J. Galmes, J. Cifre, H. Medrano, J. Flexas, 2005. Modulation of relative growth rate and its components by water stress in Mediterranean species with different growth forms. Oecologia. 145, 21-31.

25. J. Hueso, J. Cuevas, 2004. Deficit irrigation effects on flowering of loquat. Options Méditerranéennes Serie A, 58, 105-108.

26. J. S. C. Mbagwu, J. O. Osuigwe, 1985. Effects of varying levels and frequencies of irrigation on growth, yield, nutrient uptake and water use efficiency of maize and cowpeas on a sandy loam ultisol. PLANT SOIL. 84, 181-192.

27. J.Girona, M. H. Behboudian, M. Mata, J. Del Campo, J. Marsal, 2010. Exploring six reduced irrigation options under water shortage for "Golden Smoothee" apple : Responses of yield components over three years. Agric. Water Manage. 98, 370-375.

28. J.J. James, J.H. Richards, 2006.Plant nitrogen capture in pulse-driven systems: interactions between root responses and soil processes. J. Ecol. 94, 765-777. 
29. J.M. Costa, M.F. Ortuño, M.M. Chaves, 2007. Deficit irrigation as a strategy to save water : physiology and potential application to horticulture. J. Integr. Plant Biol. 49, $1421-1434$.

30. K. D. Montagu, K. C. Woo, 1999. Recovery of tree photosynthetic capacity from seasonal drought in the wet-dry tropics : the role of phyllode and canopy processes in Acacia auriculiformis. FUNCT PLANT BIOL. 26, 135-145.

31. K. Surendar, D. Devi, I. Ravi, Jeyakumar, P., Velayudham, K., 2013. Effect of water deficit on relationship between yield and physiological attributes of banana cultivars and hybrids. African J. Plant Sci. 7, 374-383.

32. Kebede Woldetsadik., 2003. Shallot (Allium cepa var, ascolonicum) responses to plant nutrients and soil moisture in a sub-humid tropical climate. PhD. Thesis. Swedish University of Agricultural Sciences, Alnarp, Sweden.

33. L. S. Bates, R. P. Waldren, I. D. Teare, 1973. Rapid determination of free proline for water-stress studies. Plant and soil, 39, 205-207

34. L.S. Pereira, T. Oweis, A. Zairi, 2002. Irrigation management under water scarcity. Agric. Water Manage. 57, 175-206

35. L'Economiste, 2018. Culture de l'oignon: Comment Fès-Meknès est devenue championne. Accesed on 12 May 2020. https://www.leconomiste.com/article/1032222culture-de-l-oignon comment-fes-meknes-est-devenue-championne.

36. M. Bzioui, 2004.Rapport national 2004 sur les ressources en eau au Maroc. UN WaterAfrica, Nov.2004.

37. M. H. Ali, M. R. Hoque, A. A. Hassan, A. Khair, 2007. Effects of deficit irrigation on yield, water productivity, and economic returns of wheat. Agric. Water Manage. 92, 151161.

38. N. El Jaouhari, A. Abouabdillah, R. Bouabid, M. Bourioug, L. Aleya, M. Chaoui, 2018. Assessment of sustainable deficit irrigation in a Moroccan apple orchard as a climate change adaptation strategy. Sci. Total Environ. 642, 574-581.

39. N.C. Turner, 1981. Techniques and experimental approaches for the measurement of plant water status. Plant Soil. 58, 339-366.

40. P. D. Hare, W. A. Cress, 1997. Metabolic implications of stress-induced proline accumulation in plants. Plant Growth Regul., 21, 79-102.

41. P. Steduto, T.C. Hsiao, E. Fereres, D. Raes, 2012. Crop Yield Response to Water, FAO Irrigation and Drainage Paper No. 66. Rome, Italy.

42. Q. Chai, Y. Gan, C. Zhao, H.L. Xu, R.M. Waskom, Y. Niu, K.H.M. Siddique, 2016. Regulated deficit irrigation for crop production under drought stress. A review. Agron. Sustain. Dev. 36, 1-21.

43. R. A. L. Kanton, L. Abbey, R. H. Gbene, 2003. Irrigation schedule affects onion (Allium cepa L.) growth, development, and yield. J. Veg. Crop Prod. 9, 3-11.

44. R. López-Urrea, F. M. de Santa Olalla, A. Montoro, P. López-Fuster, 2009. Single and dual crop coefficients and water requirements for onion (Allium cepa L.) under semiarid conditions. Agric. Water Manage. 96, 1031-1036.

45. R.G. Allen, L.S.Pereira, D. Raes, M. Smith and others, 1998. Crop Evapotranspiration Guidelines for Computing Crop Water Requirements-FAO Irrigation and Drainage Paper 56. FAO, Rome vol. 300, D05109.

46. R.G. Evans, E.J. Sadler, 2008. Methods and technologies to improve efficiency of water use. Water Resour. Res. 44, 1-15.

47. S. Ayas, 2019. Water-Yield Relationships in Deficit Irrigated Onion. TURJAF. 7, 13101320 .

48. S. P. Sharma, D. I. Leskovar, K. M. Crosby, A. Volder, A. M. H., Ibrahim, (2014). Root growth, yield, and fruit quality responses of reticulatus and inodorus melons (Cucumis 
melo L.) to deficit subsurface drip irrigation. Agricultural Water Management, 136, $75-$ 85.

49. Shock, C.C., E.B.G. Feibert L.D. Saunders., 2000.Irrigation criteria for drip-irrigated onion. Horticultural Science. 35, 63-66

50. T. C. Hsiao, (1973). Plant responses to water stress. Annu. Rev. Plant Physiol. 24, 519570.

51. T.A. Howell, 2001. Enhancing water use efficiency in irrigated agriculture. Agron. J. 93, 281-28.

52. Y. Brouzyine, A. Abouabdillah, A. Hirich, R. Bouabid, R. Zaaboulc, L. Benabdidate, 2018. Modeling sustainable adaptation strategies toward a climate-smart agriculture in a Mediterranean watershed under projected climate change scenarios. Agric. Syst. $162,154-163$.

53. Z. Karim, (1981). Water use by onion in grey terrace soil. Bangladesh Horticulture. 9, 6164. 